The Journal of SPORT, 2013, 2(2), 154-174

(C) Kent State University

\title{
A Preliminary Investigation of Job Satisfaction of Compliance Officers at NCAA Division II institutions
}

\author{
Jennifer Parsons \\ Ashland University \\ Lance P. Kaltenbaugh \\ Ashland University \\ Ken Brubaker \\ Ashland University \\ Bryce Winters \\ Ashland University \\ Sabrina Cali \\ Cleveland State University
}

\begin{abstract}
Identifying what job characteristics influence employee satisfaction requires the ability to effectively study the environment that influences the sense of belonging and a fulfillment of social needs. The primary purpose of this study was to investigate aspects of employment that influence job satisfaction of NCAA Division II compliance officers. Job satisfaction was measured by the Job Satisfaction Survey (JSS), which consisted of nine subscale measures that relate to employee job satisfaction and strongly examines perceptual and attitudinal variables (Spector, 1997). Participants for this study consisted of 206 NCAA Division II compliance officers. Descriptive analysis was conducted to determine to what degree NCAA Division II compliance officers express their job satisfaction. Results suggested that supervision, co-workers, and nature of work were the three highest-ranking measures of job satisfaction. The compliance officers appeared satisfied when given autonomy over their job, played a greater role in organizing the environment of intercollegiate athletics and had productive work relationships with athletic staff.
\end{abstract}




\section{Introduction}

For over a century, critics have condemned the substantial athletic budgets compared to meager academic departments' resources, the scandals associated with athletes' grade manipulation or outright cheating, the exploitation of the athletes, and the big business mentality leading to a win-at-all-cost attitude at many institutions of higher learning (Beyer \& Hannah, 2000). In some instances, powerful alumni donors and athletic directors would "dominate weak presidents, disorganized faculties, and powerless students" (Sojka, 1983, p. 58), while strongly encouraging interest in and support of their athletic teams as a means of creating national recognition and prestige.

From its inception in 1905, the National Collegiate Athletic Association (NCAA) has adopted thousands of rules and regulations to protect the student-athletes and prevent unethical advantages (Covell \& Barr, 2001). Many of the initial rules focused on consistency in eligibility across institutions. In the late 1970s and early 1980s, there was a call for reform to increase the academic performance of athletes (Covell \& Barr, 2001). Perhaps the most noted changes occurred after abysmal athlete graduation rates (less than $50 \%$ in football) were publicized in the early 1980 s (Heck \& Takahashi, 2006). Despite instituting new rules and harsh penalties, scandals involving college athletes have continued to make headlines.

The NCAA develops and implements regulations for all levels of competition (Division I, II, III) in areas varying from graduation rates to eligibility to improper benefits (NCAA.org) The vast array of NCAA bylaws, rules and regulations are monitored by each member institution's department or division of compliance. The compliance officer is responsible for monitoring, reporting, and enforcing the NCAA bylaws at his/her institution (Kihl, 2009). Compliance officers are also involved in other aspects of athletic programs from marketing, development, budget, strength and conditioning and coaching (Copeland, 2008). Furthermore, The National Association of Athletics Compliance (NAAC) exists to give compliance directors a greater role in organizing the environment of intercollegiate athletics. The NAAC helps compliance professionals 
by providing compliance solutions on behalf of college athletics (Copeland). Annually, the NAAC holds a national convention that focuses on professional development and provides the opportunity for athletic directors to discuss key issues and concerns within collegiate sports. One of the NAAC's focus points in past years has been to develop standards for professionals to hire well-qualified and prepared compliance administration.

In addition to possessing a thorough understanding of the latest NCAA rules manual and being familiar with the NAAC guidelines, the compliance officer also must report infractions that could ultimately jeopardize the success of an athletic program and tarnish the reputation of an institution. As stated by Pierce, Kaburakis, and Fielding (2008), "Coaches need to win, whereas compliance officers need coaches to abide by the rules" (p. 87). Due to changes in coaching tenure and the need for a winning season to hold one's job, these factors can impact the chances for behavior that violates NCAA rules. As a result, the role of the compliance officer is incredibly important and demanding.

\section{Job Satisfaction}

Within institutional, industrial, and social psychology research, the concept of job satisfaction is a central research theme (Bardett \& Weeks, 2005; Henne \& Locke, 1985) and is viewed as a goal of organizations (Balzer, Kihm, Smith, Bachlochi, Robie, \& Parra, 1997; Locke, 1976). As research continues to examine the complex and dynamic process of job satisfaction, there is a sustained attempt to investigate and define the various definitions of job satisfaction in the literature (Henning \& Terranova, 2011; Pettit, Goris, \& Vaught, 1997). Locke (1976) was one of the first researchers to define job satisfaction as "a pleasurable or positive emotional state resulting from the appraisal of one's job or job experiences" (p. 1300). Later work by Locke and Latham (1990) simplified the definition of job satisfaction as the favorableness or unfavorableness with which employees view their work. Balzar et al. (1997) refined the definition of job satisfaction as feelings that employees have regarding their work environment and their expectations towards work. Thus, job satisfaction can be recognized 
as what one wants or values from a job (Brief \& Weiss, 2002). These authors suggested that in any job the way in which an employee viewed his or her work influenced the amount of satisfaction (morale) he or she received from the job (Heyle, 2007; Spector, 1997).

Identifying what job characteristics made employees satisfied required the ability to effectively study the environment that influenced the sense of belonging and a fulfillment of social needs. These factors are conducive to a quality work life. Previous research has suggested that the work environment can have a major influence on job satisfaction (Kulhavy \& Schwartz, 1981; Llorente \& Macias, 2005). Gordon, Anderson, and Bruning (1992), added that institutions also have a responsibility to commit themselves to their employees' welfare, rights, and product quality. Being able to link characteristics of work identity with specific job characteristics serves as important antecedents of job satisfaction.

\section{Work Environment}

The role a positive work environment played in job satisfaction has also been examined. The prevailing argument by Morrison (2002) was that organizations must be responsive to not only providing a job and income, but a constructive work environment as well. Carlson and Mellor (2004) stated that "satisfaction is expected when a job allows an incumbent to be engaged in intrinsic forms of self-expression" (p. 238). Simply put, employees who were engaged in work practices were more likely to develop the positive beliefs and attitudes associated with employee engagement, enhanced performance, and job satisfaction.

Further research suggested that when employees were content with their organization, they felt their work and contributions were valuable assets and would, to a certain extent, influence the amount of satisfaction (morale) they received from the job (Eisenberger, Fasolo, \& Davis-LaMastro, 1990; Pettit et al., 1997). King, Lahiff, and Hatfield (1988) reported that there was a "consistently clear and positive pattern of relationships between an employee's perceptions of their work and his or her job satisfaction" (p. 36). Thus, employees who were able to improve their work 
experience often enhanced their overall well-being and were most likely to succeed (Brown \& Mitchell, 1993; Eisenberg \& Goodall, 2004; Sias, 2005; Wheatley, 2001).

\section{Employee Motivation}

A growing body of research investigated employees' work and motives and how it explained satisfaction with the job (C. M. Anderson \& Martin, 1995). Zhang, DeMichele, and Connaughton (2004) suggested that certain motivational factors contributed to job satisfaction such as "achievement, recognition, work itself, responsibility, advancement, and professional growth" (p. 187).

Likewise, there were positive correlations between job satisfaction and an employees' mental well-being, commitment to the job, and motivational factors (Kreitner \& Kinicki, 2006). King et al. (1988) also reported that there was a "consistently clear and positive pattern of relationships between an employee's perceptions of their job duties and responsibilities and his or her job satisfaction" (p. 36). Studies demonstrated that when people's needs were met through a satisfying work environment they were more likely to remain at their job and experience satisfaction (Rubin, 1993). Conversely, unfulfilled needs resulted in counterproductive work behaviors and high degrees of dissatisfaction with their job (R. B. Rubin \& Rubin, 1992), which contributed to feelings of dissatisfaction with superiors, job duties and responsibilities, and ultimately the institution (Jablin \& Krone, 1994). Finally, Zhang et al. (2004) agreed that job satisfaction was not merely an employee's responsibility but an organization's ability to satisfy the "needs, values, and expectations of employees" (p. 187). Various factors that may influence whether an individual leaves a career, but job satisfaction has been an indicator in regards to staying or leaving a profession or organization.

\section{Challenges for Compliance Officers}

Administrators in Higher Education are realizing that employees cannot be taken for granted. Institutions are dealing with employees who look for job satisfaction, who believe in personal options and independence, and who want meaningful work 
(D’Aprix, 1996). Previous research suggested that a meaningful work environment increased job satisfaction (D’Aprix, 1996; Downs, Clampitt, and Pfeiffer, 1988; Pettit et al., 1997; Pincus, 1986; Sias, 2005). Similar findings suggested there were various organizational and individual work environment variables such as "internal communication, organizational structure, political climate, participation in decision making, independence, benefits, and job effectiveness" (Zhang et al., 2004, p. 188) that provided increased levels of satisfaction with one's work. These variables would apply to the work environment of NCAA compliance officers.

With the heightened awareness of adhering to the rules and regulations set forth by the NCAA, not providing a work environment conducive to a high level of job satisfaction could ultimately impact the overall compliance of an athletic department. For example, lack of motivation stemming from limited opportunities for advancement or lack of recognition from superiors and co-workers, could lead to minimal effort to complete the necessary paperwork or follow-up on potential violations. With many NCAA Division II compliance officers having other work responsibilities, the worst-case scenario may be a sense of apathy with their role as compliance officer compared to more personally rewarding positions they also hold. To better understand the role job satisfaction plays in institutional compliance, more research is warranted.

\section{Purpose of the Study}

Research assessing job satisfaction and work environment on college campuses has been performed. Studies examining college and university presidents (Perrakis, Galloway, Hayes, \& RobinsonGaldo, 2011), faculty members (Bozeman \& Gaugahan, 2011; Marston \& Brunetti, 2009) and campus recreation professionals (Kaltenbaugh, 2009; Stier, Schneider, Kampf, \& Gaskins, 2010) suggest that work environment may play a role in the participants' overall satisfaction.

Although NCAA Division I compliance has garnered frontpage attention, the position of compliance officer has received little consideration with regard to job satisfaction. To handle the workload 
of compliance at Division I level, many institutions have entire departments devoted exclusively to monitoring coaches, athletes, and other individuals who fall under the NCAA rules and regulations. In stark contrast, the Division II compliance officer has limited resources and is often responsible for other areas in the athletic department such as coaching or administrative duties.

The majority of available research focuses exclusively on the Division I level. The purpose of this study is to provide an initial examination into the factors that influence the job satisfaction surrounding NCAA Division II compliance officers.

\section{Survey}

\section{Methods}

Participants completed a web-based version of the Job Satisfaction Survey (JSS) which measured nine facets of job satisfaction. The 36-item survey (Spector, 1985) included facets relating to pay, promotional opportunities, fringe benefits, contingent rewards, supervision, co-workers, nature of work, communication, and operating procedures. Respondents were asked to indicate their level of agreement using a 6-point Likert-type scale ranging from "strongly agree" to "strongly disagree."

\section{Subjects}

The accessible population of this study was 260 compliance officers at National Collegiate Athletic Association (NCAA) Division II institutions listed on the NCAA website (www.ncaa.com). A total of 134 surveys were returned resulting in a $52 \%$ response rate of useable data for purposes of data analysis. According to Krejcie and Morgan (1970) 125 respondents were needed to reach a 95 percent confidence level which substantiates the studies sample size. An additional 12 incomplete surveys were returned; these surveys were deemed unusable and were discarded.

A cover letter, explaining the purpose of the study, was included in the web-based version of the JSS which was sent to each institution's compliance officer (one survey per institution). Participants were asked to anonymously, and on a voluntary basis, fill out the online JSS through Survey Monkey. To preserve 
anonymity of the respondents, no identifying characteristics of the subjects were used. All information gathered was kept confidential. The data-collection process was completed in seven weeks from June to August 2012.

\section{Scale Properties - Reliability}

\section{Results}

The JSS (Spector, 1985) is a well-established instrument that has been repeatedly investigated for reliability and validity. Reliability results showed that 11 of the 12 subscales used to measure job satisfaction were above the minimum coefficient alpha of .70 (Fraenkel \& Wallen, 2003) and were deemed to be reliable. Operating procedures was the only subscale that did not meet the 0.70 coefficient alpha standard for internal consistency. Overall, the reliability of the nine subscales was 0.92 , well above the traditional cutoff.

\section{Descriptive Analysis of Job Satisfaction}

To interpret mean scores of the JSS, Spector (1994) uses an absolute approach. Since the JSS uses 6-point agree-disagree response choices, a mean score of 3.5 is the arbitrary cut score to represent dissatisfaction versus satisfaction. The survey data were analyzed descriptively with means, per the guidelines of the JSS. Means were used to answer what degree does NCAA Division II compliance officers express their job satisfaction. The content of the JSS investigated nine sub facets which included pay, promotional opportunities, fringe benefits, contingent rewards, supervision, coworkers, nature of work, communication, and work conditions.

Respondents were asked specific questions relating to their job. A mean score above the mid-point mean score of 3.5 indicates that participants were satisfied with their job and dissatisfied when below. As shown in Table 1, supervision $(\mathrm{M}=5.01)$ had the highest mean score whereas pay $(\mathrm{M}=2.93)$ had the lowest mean score. An overall score of 3.93 indicated that the respondents were satisfied with their job. The data indicated that supervision, fringe benefits, contingent rewards, co-workers, nature of work, and communication were above 3.5. Pay, promotion, and operating procedures were facets in which compliance officers scored below the scale's mean. 
Table 1 depicts the mean scores of the NCAA Division II compliance officer sample.

\begin{tabular}{|c|c|c|c|c|}
\hline JSS Sub Facets & Individual item & Mean & $\begin{array}{l}\text { Std. } \\
\text { Dev. }\end{array}$ & $\begin{array}{l}\text { Overall Sub } \\
\text { Facet Mean }\end{array}$ \\
\hline Pay & $\begin{array}{l}\text { I feel I am being paid a fair amount for the work } \\
\text { I do. } \\
\text { Raises are too few and far between. } \\
\text { I feel unappreciated by the organization when I } \\
\text { think about what they pay me. } \\
\text { I feel satisfied with my chances for salary } \\
\text { increases. }\end{array}$ & $\begin{array}{l}3.22 \\
2.22 \\
3.46\end{array}$ & $\begin{array}{l}1.597 \\
1.470 \\
1.564\end{array}$ & 2.93 \\
\hline Promotion & $\begin{array}{l}\text { There is little chance for promotion at my job. } \\
\text { Those who do well on the job stand a fair } \\
\text { chance of being promoted. } \\
\text { People get ahead as fast here as they do in other } \\
\text { places. } \\
\text { I am satisfied with my chances for promotion. }\end{array}$ & $\begin{array}{l}3.06 \\
3.33 \\
2.92 \\
3.10\end{array}$ & $\begin{array}{l}1.574 \\
1.348 \\
1.208 \\
1.471\end{array}$ & 3.10 \\
\hline Supervisor & $\begin{array}{l}\text { My supervisor is quite competent in doing } \\
\text { his/her job. } \\
\text { My supervisor is unfair to me. } \\
\text { My supervisor shows little interest in the } \\
\text { feelings of subordinates. } \\
\text { I like my supervisor. }\end{array}$ & $\begin{array}{l}4.78 \\
5.25 \\
4.74 \\
5.25\end{array}$ & $\begin{array}{l}1.340 \\
1.122 \\
1.337 \\
.979\end{array}$ & 5.01 \\
\hline Fringe Benefits & $\begin{array}{l}\text { I am not satisfied with the benefits I receive. } \\
\text { The benefits we receive are as good as most } \\
\text { other organizations offer. } \\
\text { The benefit package we have is equitable. } \\
\text { There are benefits we do not have which we } \\
\text { should have. }\end{array}$ & $\begin{array}{l}4.19 \\
4.17 \\
4.38 \\
3.51\end{array}$ & $\begin{array}{l}1.537 \\
1.433 \\
1.225 \\
1.408\end{array}$ & 4.06 \\
\hline $\begin{array}{l}\text { Contingent } \\
\text { Rewards }\end{array}$ & $\begin{array}{l}\text { When I do a good job, I receive the recognition } \\
\text { for it that I should receive. } \\
\text { I do not feel that the work I do is appreciated. } \\
\text { There are few rewards for those who work here. } \\
\text { I don't feel my efforts are rewarded the way they } \\
\text { should be. }\end{array}$ & $\begin{array}{l}4.10 \\
3.89 \\
3.66 \\
3.34\end{array}$ & $\begin{array}{l}1.378 \\
1.535 \\
1.497 \\
1.441\end{array}$ & \\
\hline
\end{tabular}

\begin{tabular}{llll}
\hline Operating & Many of our rules and procedures make doing a & 3.47 & 1.434 \\
Conditions & $\begin{array}{l}\text { good job difficult. } \\
\text { My efforts to do a good job are seldom blocked }\end{array}$ & $3.77 \quad 1.476$ \\
& by red tape.
\end{tabular}




\begin{tabular}{|c|c|c|c|c|}
\hline & $\begin{array}{l}\text { I have too much to do at work. } \\
\text { I have too much paperwork. }\end{array}$ & $\begin{array}{l}2.40 \\
2.23\end{array}$ & $\begin{array}{l}1.158 \\
1.232\end{array}$ & 2.97 \\
\hline Co-Workers & $\begin{array}{l}\text { I like the people I work with. } \\
\text { I find I have to work harder at my job because } \\
\text { of the incompetence of people I work with. } \\
\text { I enjoy my coworkers. } \\
\text { There is too much bickering and fighting at } \\
\text { work. }\end{array}$ & $\begin{array}{l}5.31 \\
3.54 \\
5.15 \\
4.20\end{array}$ & $\begin{array}{c}.760 \\
1.454 \\
.854 \\
1.496\end{array}$ & 4.55 \\
\hline $\begin{array}{l}\text { Nature of } \\
\text { Work }\end{array}$ & $\begin{array}{l}\text { I sometimes feel my job is meaningless. } \\
\text { I like doing the things I do at work. } \\
\text { I feel a sense of pride in doing my job. } \\
\text { My job is enjoyable. }\end{array}$ & $\begin{array}{l}4.61 \\
4.87 \\
5.19 \\
4.84\end{array}$ & $\begin{array}{l}1.424 \\
1.116 \\
.943 \\
1.042\end{array}$ & 4.88 \\
\hline $\begin{array}{l}\text { Communi- } \\
\text { cation }\end{array}$ & $\begin{array}{l}\text { Communications seem good within this } \\
\text { organization. } \\
\text { The goals of this organization are not clear to } \\
\text { me. } \\
\text { I often feel that I do not know what is going on } \\
\text { with the organization. } \\
\text { Work assignments are not fully explained. }\end{array}$ & $\begin{array}{l}3.66 \\
4.46 \\
3.92 \\
4.37\end{array}$ & $\begin{array}{l}1.360 \\
1.401 \\
1.436 \\
1.254\end{array}$ & 4.10 \\
\hline
\end{tabular}

\section{Contribution of Demographic Factors}

The subjects surveyed were NCAA Division II compliance officers. Demographics of the respondents revealed that $41 \%$ identified themselves as male, and $59 \%$ as female. As to the age of the subjects, $0.7 \%$ were under $25,45.5 \%$ were $26-35,22.4 \%$ were $36-45,22.4 \%$ were $46-55$, and $9 \%$ were 60 or older. Participation by type of institution was $51.5 \%$ public and $48.5 \%$ private. As to the student population of the institution, $77(57.5 \%)$ had less than 5,000 students; 47 (35.1\%) were between 5,001 and 15,000; 8 (6\%) between 15,001 and 25,000; $1(0.7 \%)$ between 25,001 and 40,000; and $1(0.7 \%)$ had over 40,000 . Regarding years in position, 46 $(34.3 \%)$ reported they had been working for the organization for more than 5 years, $40(29.9 \%)$ subjects between 3 and 5 years, 43 (32.1\%) subjects between 1 and 3 years, and the rest, $5(3.7 \%)$, had worked for the organization less than one year. Description of the participant demographic composition is presented in Table 2. 
Table 2 Demographic Characteristics of NCAA Division II Compliance Officers (N 134)

Characteristics Compliance Officers

\begin{tabular}{lrr}
\cline { 2 - 2 } & $\underline{\mathrm{n}}$ & $\underline{0}$ \\
& & \\
\hline & & \\
Gender & & \\
Male & 55 & 41.0 \\
Female & 79 & 59.0 \\
Age Classification & & \\
$18-25$ & 1 & 0.7 \\
$26-35$ & 61 & 22.4 \\
$36-45$ & 30 & 22.4 \\
$46-55$ & 30 & 9.0 \\
$60+$ & 12 & \\
& & 3.7 \\
Years in Position & & 32.1 \\
Less than 1 year & 5 & 29.9 \\
$2-3$ years & 43 & 34.3 \\
$4-5$ years & 40 & \\
More than 6 years & 46 &
\end{tabular}

\section{Discussion}

The current study presented an initial step in exploring the dynamics of job satisfaction as expressed by compliance officers of NCAA Division II institutions. The results indicated that the job dimensions for supervision, co-workers, and nature of work were the three highest scores above the mean. Items that measured fringe benefits and contingent rewards also had mean scores that scored above average in terms of job satisfaction. Based on the current findings pay, promotion, and operating conditions were below the mid-point of the scale. These three sub facets did not score as highly on the JSS, which could indicate areas in which these compliance officers were less satisfied with their job. 


\section{Supervision}

Compliance officers in this study reported more satisfaction with supervision than with any other facet of job satisfaction. Ryan, Clopton, and Irwin (2008) suggested that there was a highly significant relationship between supervisory support and job satisfaction. One of the many roles of an athletic director is to supervise the compliance officer's efforts to help ensure the department follows NCAA rules and regulations.

Participants reported favorably with supervision when they are provided the opportunity to have input into departmental policy issues. Work by Spector (1997) summarized that when employees participate in making decisions for the organization they feel supportive and respected. Since supervision scored positively among participants, athletic directors might be giving compliance officers the opportunity to make those important decisions that positively affect his or her work environment.

As stated by Spector (1985), the amount of autonomy given to employees had an effect on an employees' job satisfaction. The findings from the current study suggest that compliance officers value the level of autonomy in performing their job and would appear to appreciate appropriate supervision. An essential component of supervision seems to be that compliance officers are satisfied when they are given a greater role in organizing the environment of intercollegiate athletics. Having the autonomy to complete their day to day job experiences without much resistance could be one of the explanatory factors on participants' satisfaction with their job.

\section{Co-Workers}

Building productive relationships with co-workers can impact the degree of overall job satisfaction. Creating environments of trust and honesty while holding similar values may be the job of the athletic administration, but almost certainly influences the productivity and level of conflict within of the overall department (Kerwin \& Doherty, 2012). The level of communication and satisfaction with coworkers in this study appeared to have a positive influence on the overall attitude and satisfaction of the participants. 
Thus, compliance officers appreciated the relationships built with their coworkers.

Achieving and maintaining NCAA compliance requires input from many members of an athletic department. A compliance officer's level of job satisfaction is related to the relationships and the characteristics of the groups to which they belong. Previous research (Beehr, et al 2006; Holloway, 1995) indicated that employees who were able to develop effective interpersonal relationships with their peers reported being more satisfied with their co-worker and work conditions. A negative work environment could ultimately influence interaction with peers and co-workers having a significant impact on a compliance officer's attitude and behavior. Minimizing personal and professional conflicts within the athletic department personnel is likely to have an impact on not only the productivity of compliance initiatives, but also on the overall job satisfaction of the individuals involved.

\section{Nature of Work}

The current study indicated that respondents were satisfied with the nature of the work itself. According to Spector (1997) nature of work includes job challenges, variety and scope of work conditions, freedom to try new things, and other outcomes such as employee retention. These factors of a work environment must fit with the culture of an athletic department or division to increase job satisfaction, otherwise compliance officers and other employees may look elsewhere to find a workplace better suited to his or her needs.

A good working environment will not only help employees remain satisfied with what they do, but also enhance retention and future recruitment efforts (Kaltenbaugh, 2009). Employee turnover has been linked to lower job satisfaction regardless of industry (Long $\&$ Thean, 2011). Reducing turnover has been a noteworthy concern for any variety of organizations due to the important role of building an organization's human capital. Organizations can influence the work environment by providing appropriate training, adequate compensation and advancement opportunities, as well as monitoring the employees' level of satisfaction with their position (Kazi, Aziz, \& Zadeh, 2012). 
These factors would be no different for the position of compliance officer. Turnover of compliance officers could cost institutions in terms of time and money spent on training and recruitment as well as potentially gaps in reporting data to the NCAA. Knowing how to use a positive work environment to increase or maintain compliance officer's satisfaction and reduce turnover is a key to developing a high-performance workforce.

\section{Implications and Future Research}

The results of this study provide an initial examination into the job satisfaction of compliance officers within NCAA Division II member institutions. The findings add to the overall existing body of work in the job satisfaction field and advance the limited knowledge that pertains specifically to compliance officers' work environments. The role of the compliance officer in monitoring and enforcing rules is important to the overall success and reputation of the athletic department. The potential benefits stemming from providing a positive work environment are enhanced self-motivation, level of communication, and rapport with co-workers. In addition, these findings may provide some direction for athletic directors who are responsible for the hiring and supervision of compliance officers. By providing the needed support and avenues of communication, retention of compliance officers might be enhanced which would create continuity in reporting to the organization's governing body.

Although the present study used the Job Satisfaction Survey's nine variables to determine job satisfaction, various athletic directors and institutions might have different variables or research questionnaires to measure job satisfaction more effectively. Other factors or subscales may have a more direct impact on job satisfaction than those used for this study. It is important to state that the findings of this study may only be generalizable to the population of NCAA Division II athletic departments included in the study. An examination of those charged with compliance duties across all levels of athletic administration from interscholastic to professional and elite international athletic associations is also recommended. 
Finally, further research is needed to determine the underlying causes of why NCAA Division II compliance officers are satisfied or dissatisfied with their jobs. Are there specific experiences that can effect job satisfaction? If so, what would be the consequences of such experiences? In other words, what could potentially happen if compliance officers were not satisfied in their job (besides being personally unhappy)? Other avenues of research could investigate whether success of the school's athletic program, size of institution, lack of training, or job responsibilities has any correlation to a compliance officer's job satisfaction. 


\section{References}

Anderson, C. M., \& Martin, M. M. (1995). Why employees speak to coworkers and bosses: Motives, gender, and organizational satisfaction. Journal of Business Communication, 32(3), 249.

Balzer, W.K., Kihm, J.A., Smith, P.C., Irwin, J.L., Bachlochi, P.D., Robie, C., Parra, L. (1997). User's manual for the job descriptive index (JDI: 1997 revision) and the job in general scales. Bowling Green, Ohio: Bowling Green State University, Department of Psychology.

Bardett, K. R. \& Weeks, K.P. (2005). Turnover intentions and voluntary turnover: The moderating rolesof self- monitoring, locus of control, proactive personality, and risk aversion. The Journal of Applied Psychology, 90 (5), 980-990.

Beehr, T.A., Glaser, K.M., Beehr, M.J., Beehr, D.E., Wallwey, D.A., Erofeev, D.(2006). The nature of satisfaction with subordinates: Its predictors and importance to supervisors. Journal of Applied Social Psychology, 36(3), 1523-1547.

Beyer, J., \& Hannah, D. (2000). The cultural significance of athletics in U.S. higher education. Journal of Sport Management, 14(2), 105-132.

Bozeman, B., \& Gaughan, M. (2011). Job satisfaction among university faculty: individual, work, and institutional determinants. Journal Of Higher Education, 82(2), 154-186.

Brief, A. P., \& Weiss, H. M. (2002). Organizational behavior: Affect in the workplace. Annual Review Psychology, 53, 279-307.

Brown, K. A., \& Mitchell, T. R. (1993). Organizational obstacles: Links with financial performance, customer satisfaction, and job satisfaction in a service environment. Human Relations, $46,725-758$. 
Carlson, J. H., \& Mellor, S. (2004). Gender-related effects in the jobdesign-job- satisfaction relationship: An interactional approach. Sex Roles, 51(3/4), 237-247.

Copeland, J. (2008). New name, broader mission: Compliance pros step up. NCAA News, 1-3.

Covell, D., \& Barr, C. A. (2001). The ties that bind: Presidential involvement with the development of NCAA division I initial eligibility legislation. Journal of Higher Education, 72(4), 414-452.

D'Aprix, R. M. (1996). Communicating for change: Connecting the workplace with the marketplace. San Francisco: Jossey-Bass.

Downs, C., Clampitt, P., \& Pfeiffer, A. (1988). Communication and organizational outcomes. In G. Goldhaber \& G. Barnett (Eds.), Handbook of organizational communication (pp. 171211). Norwood, NJ: Ablex.

Eisenberg, E. M., \& Goodall, H. L., Jr. (2004). Organizational communication: Balancing creativity and constraint $\left(4^{\text {th }} \mathrm{ed}\right.$.). Boston: Beford/St. Martin's Press

Eisenberger, R., Fasolo, P., \& Davis-LaMastro, V. (1990). Perceived organizational support and employee diligence, commitment, and innovation. Journal of Applied Psychology, 75 (1), 5159.

Fraenkel, J., \& Wallen, N. (2003). How to design and evaluate research in education. New York: McGraw-Hill.

Gordon, W. I., Anderson, C. M., \& Bruning, S. D. (1992). Employee perceptions of corporate partnership: An affective-moral quid pro quo. Employee Responsibilities and Rights Journal, 5, $75-85$. 
Heck, R. H., \& Takahashi, R. (2006). Examining the impact of proposition 48 on graduation rates in division IA football and program recruiting behavior: Testing a policy change model. Educational Policy, 20(4), 587-614.

Henne, D., \& Locke, E. A. (1985). Job dissatisfaction: What are the consequences? International Journal of Psychology, 20, 221240 .

Henning, J.M. \& Terranova, A. B. (2011). National collegiate athletic association division and primary job title of athletic trainers and their job satisfaction or intention to leave athletic training. Journal of Athletic Training, 46(3), 321-318.

Heyle, L. E. (2007). An examination of the effect of job autonomy on job satisfaction. Proquest Dissertations and Theses. (UMI No. AAT 1441783)

Holloway, E.L. (1995). Clinical supervision: A systems approach. Research in Organizational Behavior, 2, 37-71.

Jablin, F. M., \& Krone, K. J. (1994). Task/work relationships: A life space perspective. In M. L. Knapp \& G. R. Miller (Eds.), Handbook of interpersonal communication (pp. 621-675). Thousand Oaks, CA: Sage.

Kaltenbaugh, L. (2009). A study on job satisfaction among campus recreation administrators at four-year public and private institutions. Recreational Sports Journal, 33(2), 89-101.

Kazi, G., Aziz, S., \& Zadeh, Z. F. (2012). The contribution of organizational variables and its impact on job turnover and job satisfaction of employee's. Interdisciplinary Journal Of Contemporary Research In Business, 3(10), 1067-1073. 
Kerwin, S., \& Doherty, A. (2012). An investigation of the conflict triggering process in intercollegiate athletic departments. Journal of Sport Management, 26(3), 224-236.

Kihl, L. (2009). Pacific-10 compliance officers' morality and moral reasoning. Journal of Issues in Intercollegiate Athletics, 2, 111-149.

King, W., Lahiff, J., \& Hatfield, J. (1988). A discrepancy theory of the relationship between communication and job satisfaction. Communication Research Reports, 5, 36-43.

Kulhavy, R. W., \& Schwartz, N. H. (1981). Tone of communication and climate perceptions. Journal of Business Communication, 18(1), 17-24.

Kreitner, R., \& Kinicki, A. (2006). Organizational Behavior. New York: McGraw Hill.

Krejcie, R. V. \& Morgan, D. W. (1970). Determining sample size for research activities. Educational Psychology Measures, 30(3), 607-610.

Llorente, R. M. B., \& Macias, E. F. (2005). Job satisfaction as an indicator of the quality of work. The Journal of SocioEconomics, 34, 656-673.

Locke, E. A. (1976). The nature and causes of job satisfaction. In M. D. Dunnette (Ed.), Handbook of industrial and organizational psychology (pp. 1297-1349). Chicago: Read McNally.

Locke, E. A., \& Latham, G. P. (1990). Work motivation and satisfaction: Light at the end of the tunnel. American Psychological Science, 1(4), 240-246. 
Long, C, S. \& Thean, L. Y. (2011). Relationship between leadership style, job satisfaction and employees' turnover intention: A literature review. Research Journal of Business Management, 5(3), 91-100.

Marston, S. H., \& Brunetti, G. J. (2009). Job satisfaction of experienced professors at a liberal arts college. Education, $130(2), 323-347$.

Morrison, T. (2002). How can values be taught in the university? Peer Review, 4(4), 4-7.

Perrakis, A. I., Galloway, F. J., Hayes, K. K., \& Robinson-Galdo, K. (2011). Presidential satisfaction in higher education: An empirical study of two- and four-year institutions. Journal of Higher Education Policy And Management, 33(1), 57-66.

Pettit, J. D., Goris, J. R., \& Vaught, B. C. (1997). An examination of organizational communication as a moderator of the relationship between job performance and job satisfaction. The Journal of Business Communication, 34(1), 81-89.

Pierce, D., Kaburakis, A., \& Fielding, L. (2008). Compliance officers' guide to navigating NCAA student-athlete reinstatement cases involving amateurism violations. Journal of Issues in Intercollegiate Athletics, 87-106.

Pincus, D. (1986). Communication satisfaction, job satisfaction, and job performance. Human Communication Research, 12, 395419.

Rubin, A. M. (1993). The effects of locus of control on communication motives, anxiety, and satisfaction. Communication Quarterly, 41, 162-171. 
Rubin, R. B, \& Rubin, A. M. (1992). Antecedents of interpersonal communication motivation. Communication Quarterly, 40, 305-317.

Ryan, T., Clopton, A. \& Irwin, R. (2008). Super support: A supportive supervisor, life satisfaction, and the mediating presence of coaching satisfaction. Journal of Applied Psychology, 3, 120 - 130.

Sias, P. M. (2005). Workplace relationship quality and employee information experiences. Communication Studies, 56(4), 375395.

Sojka, G. S. (1983). Evolution of the student athlete in America. Journal of Popular Culture, 16(4), 54-67.

Spector, P. E. (1985). Measurement of human service staff satisfaction: Development of the job satisfaction survey. American Journal of Community Psychology, 13(6), 693713.

Spector, P. E. (1997). Job satisfaction: Application, assessment, causes, and consequences. London: Sage.

Stier, J. F., Schneider, R. C., Kampf, S., \& Gaskins, B. P. (2010). Job satisfaction for campus recreation professionals within NIRSA institutions. Recreational Sports Journal, 34(2), 7894.

Wheatley, M. J. (2001). Leadership and the new science:

Discovering order in a chaotic world. San Francisco: BerrettKoehler.

Zhang, J. J., DeMichele, D. J., \& Connaughton, D. P. (2004). Job satisfaction among mid-level collegiate campus recreation program administrators. Journal of Sport Behavior, 27(2), 184-212. 